\title{
Storytelling to Enhance Speaking and Listening Skills for English Young Learners: A Case Study at Language Centers in Binh Duong Province
}

\section{Du Thanh Tran}

\author{
Article history \\ Received: 14 March 2021 \\ Accepted: 10 May 2021 \\ Published: 30 June 2021
}

\section{Keywords}

Storytelling, speaking skill, listening skill, young learners

\author{
Thu Dau Mot University, Vietnam \\ Email:dutt@tdmu.edu.vn
}

\section{INTRODUCTION}

Communicative competences have been considered as the main goals of most EFL learners recently. Of these competencies, speaking and listening skills are those which take the first place in mastering a language as stated by August \& Shanahan $(2006$, p.3) that "before children learn to read and write, they must be able to speak and listen effectively". Speaking and listening skills require not only active participation from English language learners but also interactive cooperation between teachers and learners during classroom activities. Towards these goals, language teachers are expected to engage language learners and offer them as many opportunities as possible to actively practise the target language. Storytelling, just as it has been throughout history, is one of the most widely accepted teaching and learning techniques used in education (Canlibeka, 2019). Hereafter in this research, storytelling is proved to be a technique which can meet these requirements.

For a long time, Vietnamese learners of English have treated their English learning as a compulsory fulfillment to obtain a certificate or a job which may require a good command of English. These learners study English just to deal with the exams held by local schools or universities (mainly to test their grammar competence and partially their reading/writing skills as well). This thought is, in fact, out of date nowadays. Vietnam is now an official member of the World Trade Organization, and as a result, the need for international communication is on the increase. Making oneself understood or being able to communicate in English is not enough to make one's communication satisfactory and successful. Research shows that most investments in education will be less effective if elementary education or education for young language learners is ignored. This is also the reason why we aim at young learners in this research.

This study primarily aims to promote the use of storytelling techniques to improve children's speaking and listening skills. With special and endless efforts, we determine to gain the following specific purposes: (1) to measure the effectiveness of storytelling as a means to enhance children's speaking and listening skills; (2) to illustrate the 
benefits of storytelling techniques in teaching speaking and listening skills; (3) to draw sharp conclusions on children's responses and attitudes towards storytelling-based activities; (4) to give recommendations on how to choose stories and to design classroom activities based on these stories; and (5) to raise teachers' and students' awareness of the importance of teaching and learning towards communication competences at early ages. Towards these purposes, this study focuses on the following points: (1) the description of storytelling techniques and of what should be done in each stage when these techniques are employed as an educational tool in teaching and improving children's speaking and listening skills; (2) the relationship between storytelling and the development of oral competences for children; (3) the benefits of storytelling when it is used in teaching communicative skills; (4) the teaching resources including where to find stories, how to choose and design stories for classroom activities; (5) the attitudes and responses of children towards different kinds of stories and different styles of storytelling.

\section{LITERATURE REVIEW}

\subsection{Definition of story}

Mandler \& Johnson (1977) propose two different definitions of a story; one is goal-based and the other is not. These two authors argue that in addition to the four mandatory features included in Stein and Glenn's definition, an ending must be included as the final episodic category. By comparing Prince's (1973) definition and Mandler \& Johnson's (1977), it is revealed that both definitions require a change of state, either in the environment or in the protagonist.

In simpler terms, story is defined by Hornby \& Wehmeier (2000) as "a description of events and people that the writer or the speaker has invented, in order to entertain people”. Human beings have a natural ability to use verbal communication to teach, explain, and entertain, which is why storytelling is so prevalent in everyday life. Stories are particularly important in the lives of our children: "Children's hunger for stories is constant" (Andrew,1995, p.5). Stories can help children understand their world and share their experience with others. Used in real contexts, words in stories can be kept in students' minds for a longer time. Caine and Caine (1994, p.121-122) and Egan (1992, p.11) state that "stories are the way we store information in the brain. If teachers fill their students' brains with miscellaneous facts and data without any connection, these things will be tossed and hopelessly lost. But stories help us to organize and remember information and tie the content together".

"Stories are motivating, rich in language experience and inexpensive... Children have a constant need for stories" (Andrew, 1995, p.6). Available from various sources (such as from books, the Internet, or even other personal experiences), stories are quite accessible to both language teachers and learners. Stories are also easy to be designed into games, dramas or activities that can be used in class without consuming too much of teachers' time; however, they can help their students benefit remarkably from their participation in these games or activities.

\subsection{Definition of storytelling}

Storytelling has long been an interesting topic for researchers. A great number of researchers have devoted their knowledge and energy to exploiting the advantages of this technique. As stated on Wikipedia, storytelling is the art of portraying in words, images, and sounds that happened in real or imaginary events.

Gibson (1990) states that storytelling does not intrude into class time as many teachers think but can be a part of the actual lesson which can stir up the lesson, thereby helping students retain the knowledge longer. Storytelling has been proven beneficial to both teachers and students in terms of language teaching and learning by creating a positive and collaborative language learning classroom environment (Sever, 2014) and also as a convenient tool in helping students improve their linguistic skills in both their mother tongue and target language due to "numerous benefits embedded in stories" (Khodabandeh, 2018, p.24) regardless of their age or culture (Lucarevschi, 2016). Storytelling can help enlarge students' vocabulary without which they cannot speak or listen effectively (Brakke \& Houska, 2015). In the study entitled "Teacher Storytelling: A Means for Creating and Learning within a Collaborative Space - Teaching and Teacher Education", Shank (2006) claims that storytelling can help language teachers create a collaborative learning space, link the personal-private realm of teaching to the public-conceptual realm, reflect on their teaching, recognise new practical directions, and co-construct a shared understanding of good pedagogy. Educators also agree that storytelling is especially well-suited for students' exploration: As a common teaching tool, storytelling can encourage young learners to explore their unique expressiveness and heighten their abilities to communicate thoughts and feelings in the most appropriate manner. In the research entitled "An Experiential Study of Elementary Teachers with the Storytelling Process: Interdisciplinary Benefits Associated with Teacher Training and Classroom Integration", Groce (2004) finds out that storytelling is found to be effective in sparking interest and 
improving language skills in activities associated with social studies, science, language arts, and bilingual education and; therefore, is worth being considered.

Octaviana (2017) shares several reasons of why stories should be used in teaching young learners as follows: Children adore them; The story can be the core of the lesson, giving meaning and context to single words and phrases learned alone; They enjoy hearing the same stories over and over again which allows for revision to take place; Teachers gain the chance to use stories as a base for fun activities during class; The use of stories allow teachers to use a different method which lead to more variety during lessons; The use of stories and songs to expose children to English more than any other methods by allowing them to hear and understand English further.

With its own attraction and benefits, storytelling has long been of great use to EFL teachers, especially in teaching speaking and listening skills. No special equipment beyond the imagination and the power of listening and speaking is needed to create artistic images. Storytelling allows students to internalize important aspects of story beginnings and endings, settings, characters, and plot lines. It therefore provides practice in expressing ideas in thought units, using colorful and descriptive language, developing ideas in sequence, and choosing effective action words.

\subsection{Storytelling and communicative competences}

\subsubsection{Storytelling and speaking skill}

Speaking is "the process of building and sharing meaning through the use of verbal and non-verbal symbols, in a variety of contexts" (Chaney \& Burk, 1998, p.13). Discussing the relationship between storytelling and speaking skill, researchers support the idea that the former is an effective method to improve the later. Storytelling encourages students to experiment with voice, tone, eye-contact, gestures, and other facial expressions, all of which are important qualities of a good speaker. Storytelling can provide learners with techniques for holding audience's attention. Stories can also help children develop this skill because they "rely so much on words, offer a major and constant source of language experience, ... [and] they are motivating, rich in language experience (Andrew, 1995, p.6). He also states that "The experience of the story encourages responses through speaking. It is natural to express our likes and dislikes and to exchange ideas and associations related to stories we hear and read" (p.7). According to Adrian (1988, p.209), speaking English through storytelling activities is natural for children because they have a real communicative need - one of the main reasons for people to communicate in real life. Normally, the speech abilities needed for storytelling are essentially the same as those required for all speaking activities.

\subsubsection{Storytelling and listening skills}

Storytelling and listening skill have a close relationship with each other. Storytelling help students develop their listening skills, keep the class actively involved in listening activities or check whether students are following the story. Amie Sexton (2017) believes that storytelling is a good way of letting students enjoy listening and naturally develop their listening skill. Listening to stories is considered to be a good opportunity for learners to experience a real language that is well-structured with clear linguistic contexts. When listening to a story attentively, the listener is exposed to the world presented in the story with the suggestion of words employed and one's own imagination. These factors can help students self-order the events they catch while listening to stories. Research backs up the idea that "even students with low motivation and weak academic skills are more likely to listen, read, write and work hard in the context of storytelling" (U.S. Department of Education, 1986). In Andrew's view, when the storytelling activity is in progress, the teller-teacher can stop for a moment to ask his students to predict what is going to happen next (Andrew, 1995).

\section{MATERIALS AND METHODS}

\subsection{Research design}

Storytelling directly supports the development of communicative competences by enriching the teaching of speaking and listening skills. As a child cannot speak a language unless he/she has listened to that language, speaking and listening are included in this research as a unique feature.

In order to assure the validity and reliability of the research results, a mixed-method approach through survey questionnaires, interviews and observation is applied. Both quantitative and qualitative data were collected and analyzed at different stages of the research process so that the researcher could have a better understanding of the responses, the attitudes, and the progresses of the students. Firstly, the researcher collected quantitative data concerning students' genders, interests and their previous school-year results (Q1-5); students' and teachers' views and attitude towards storytelling and storytelling activities used in their English classes (Q6-12; Q13-20). Secondly, based on students' general English background, the researcher chose and designed stories. Students' attitude and behavior were carefully observed during experimental teaching sessions. Thirdly, both students and teachers were 
provided with questionnaires and interviewed after participating in experimental teaching sessions. After the interviews with the teachers were conducted individually and at various places (lasting around 10 minutes per teacher on average), the interviews with the students were conducted in class (lasting around 10 minutes per class). Finally, the researcher drew conclusions and proposed recommendations based on the results obtained throughout the study.

In favor of the viewpoint that listening and speaking skill are a well-matched couple of oral competences, these two skills are combined together during the experimental presentations. Each model teaching session consists of 03 main steps as follows: (1) pre-storytelling/pre-storywatching; (2) while storytelling/while storywatching; and (3) post-storytelling/post-storywatching. The total distributed time for each session is 45 minutes.

All of the quantitative and qualitative data collected from the observation and the questionnaire were then analyzed by using basic calculations (1) to evaluate the effectiveness of the technique; (2) to draw sharp conclusions; and (3) to produce practical recommendations for the betterment of this teaching strategy. These findings will ultimately help indicate the reliability and validity of the research.

\subsection{Research sample}

All of the storytelling teaching models in this research were conducted with the sample including 110 children aged from 10 to 15 randomly chosen from 10 different language centers in Binh Duong province ( 1 class per 1 language center). In Schumacher \& McMillan's view (1993), this sample is valid enough for a social scientific research. The language proficiency of these students is supposed to be at pre-intermediate level (based on students' previous school-year results). As the purposes of the study were clearly informed right from the beginning, the researcher received a lot of help from both the teachers and students from these centers. Apart from students' ideas, the comments from teachers in charge of these teaching sessions were also taken into consideration in the study.

\subsection{Limitations of the study}

As children's needs and preferences are varied from student to student, what we draw from this research cannot be generalized to all children in general. The research only provides the theoretical and practical background for teachers and researchers who are interested in studying as well as in applying this technique in language classrooms. Within the scope and limitations of the study, the authors would like to state hereafter that the outcomes, conclusions or theories drawn from the research only serve as reference data for those who wish to enhance their students' listening and speaking skills by means of storytelling.

\section{RESULTS AND DISCUSSION}

\subsection{Research results}

\subsubsection{Quantitative data}

The results of the questionnaires are presented in the following tables:

Table 1. Students' background profile

\begin{tabular}{lcccc}
\hline \multicolumn{1}{c}{ Questions } & \multicolumn{3}{c}{ Options } \\
\hline Q1. What subjects at school are you most & Natural sciences & Social sciences & Physical education \\
\cline { 2 - 5 } interested in? & $62.5 \%$ & $20.8 \%$ & $16.7 \%$ \\
\hline $\begin{array}{l}\text { Q2. How was your last school-year result in } \\
\text { English? }\end{array}$ & Excellent & Good & A verage & Bad \\
\cline { 2 - 5 } $\begin{array}{l}\text { Q3. How many hours do you often spend on } \\
\text { studying English a day? }\end{array}$ & Half an hour & One hour & Two hours & More \\
\cline { 2 - 5 } & $15 \%$ & $45 \%$ & $30 \%$ & $10 \%$ \\
\cline { 2 - 5 } Q4. How long have you studied English? & Two years & Three years & Four years & More \\
\hline \multirow{2}{*}{ Q5. What are your hobbies? } & $5 \%$ & $35 \%$ & $40 \%$ & $20 \%$ \\
\cline { 2 - 5 } & Reading & Arts & Sports & Others \\
\hline
\end{tabular}

Table 2. Results from the Questionnaire for the students

\begin{tabular}{lcccc}
\hline \multicolumn{1}{c}{ Questions } & \multicolumn{3}{c}{ Options } \\
\hline $\begin{array}{l}\text { Q6. How does storytelling benefit your listening } \\
\text { skill? }\end{array}$ & Very much & Much & A little & $\begin{array}{c}\text { Not at } \\
\text { all }\end{array}$ \\
\cline { 2 - 5 } & $70 \%$ & $20 \%$ & $10 \%$ & $0 \%$ \\
\hline $\begin{array}{l}\text { Q7. How does storytelling benefit your speaking } \\
\text { skill? }\end{array}$ & Very much & Much & A little & $\begin{array}{c}\text { Not at } \\
\text { all }\end{array}$ \\
\cline { 2 - 5 } & $60 \%$ & $30 \%$ & $10 \%$ & $0 \%$ \\
\hline
\end{tabular}




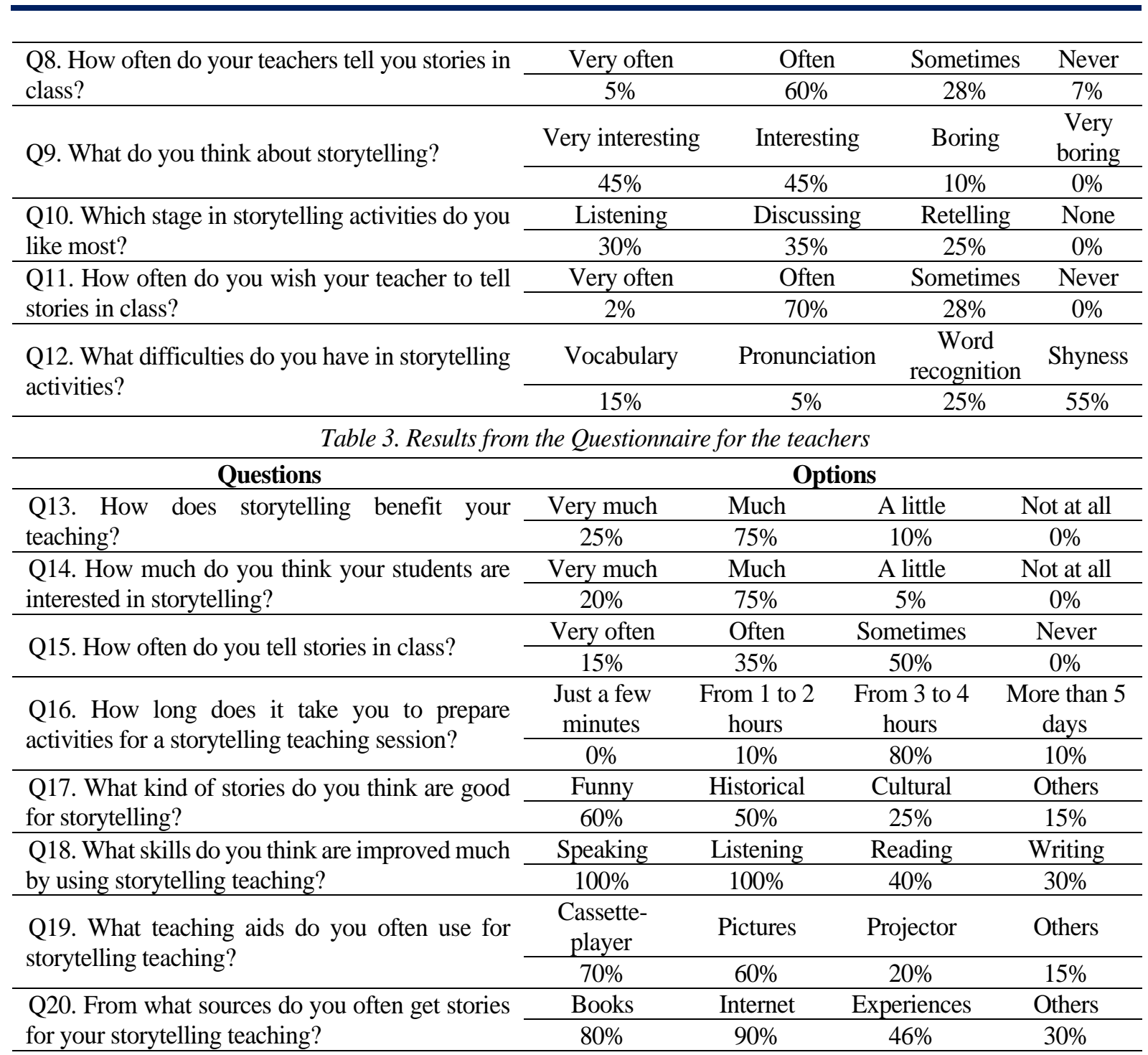

\subsubsection{Qualitative data}

To obtain qualitative data for the study, the teachers follow the activities presented in Part 3 . The stories chosen are those which (1) do not consist of too many details and characters; (2) do not consist of too many difficult-tounderstand words or expressions; (3) are appropriate with students 'language competencies; (4) are of the students' interests; (5) are easy to remember; (6) consist of students' recently-acquired grammar. A paragraph from the story "GREEDY HIPPO" can be taken as an illustration for this:

There was a greedy hippo. He ate everything in sight. From cheese to peas, chips and cake, he always had a bite. Now Hippo he was selfish. He ate everybody's food. He ate the cat's, the dog's, the cow's. He was very, very rude. One morning after breakfast, he jumped into the lake. One big splash and he was stuck. That was a big mistake. The hippo he sank deeper, then began to shout. 'Help, please help, I'm sinking. Won't someone pull me out?' The animals all pulled and pulled, as hard as they were able. Out he popped, ran past them all and ate everything on their table. The animals were angry, and thought they'd play a trick. They made a pie from fish and soap to make old Hippo sick. 'Here you are, we've made a pie, especially for you.' 'Thanks, ' he said, 'I'll eat it now. I've nothing else to do'. (Source: https://learnenglishkids.britishcouncil.org/short-stories/the-greedy-hippo).

The sample classroom procedure includes the following stages:

(1) Brainstorming stage: In this stage, the teacher (1) consolidates the formation and elicits ideas from the students; (2) briefly presents new words that will be used in the story; (3) asks questions related to the topic; (4) asks students to watch/ listen to the story and tells them what they are going to do. 
(2) Listening/Watching stage: In this stage, students are asked to watch/listen to the stories twice and do the tasks given by the teacher. Firstly, students watch/listen to the story from the teacher or the recorded material for the first time and try to understand the main idea of the story. Later, the teacher asks students to remember as many details about the story as possible.

(3) Post-watching/ listening stage: In this stage, the learners are asked to (1) discuss their own feelings about the story; (2) work in groups asking and answering questions about the story; (3) retell the story in front of the class; (iv) try to act out the story.

While delivering the teaching demonstration, the teacher makes careful observation on the students' behavior and takes notes of his findings about their motivation, attitudes and responses through their facial expression, their attentiveness, their participation and so on. He also tries to find out how the adaptability, the performance, the tone, the voice, the way, etc. of the storyteller can influence the listeners while the story itself cannot. Together with the findings from the observation, the responses from the teachers and students are also carefully recorded and taken into consideration in the process of data collection and analysis. Results from the observation and interviews with both the students and teachers indicate that storytelling proves to be a useful technique in teaching English to these students and, as a result, most of the students show their positive attitude towards storytelling-related activities in their language classes.

\subsection{Discussion}

As previously mentioned, this research is conducted with the participation of 110 children from 10 language centers in Binh Duong province. The participants are generally competent in with good pronunciation, word recognition, sufficient vocabulary in comparison with average children. The data reflect only responses and attitudes from these children in particular, and the recommendations from this research are the most suitable for similar settings.

From the collected data, the researcher comes up with the following interpretations: (1) Most of the students are interested in short stories; (2) Most of the students react positively to storytelling; (3) Storytelling generally does not require much time to be prepared and presented; (4) The vocabulary (both the words employed in the stories and those in the students' minds) can affect their learning; (5) Most of the school-girls enjoy historical and cultural stories while the school-boys show their preferences for funny stories and fictions; (6) After listening to the stories, most of the students can retell the stories without missing many details.

From experimental teaching sessions and the observational process, the following points are noted: (1) Teachers' gestures, tones and performances can attract students' attention; (2) Visual aids can help students figure out the meanings of new words, which support their comprehension; (3) Some students want to tell their own stories or experiences; (4) Most students use their own words to retell the stories; (5) Presenting new words before storytelling can effectively help students; (6) Most students enjoy the activities at the end of the teaching sessions; (7) Giving students rewards for their correct answers or good is recommended.

Through the research process and findings, storytelling appears to be very useful and suitable for the present situation of teaching English at language centers in Binh Duong province in particular and in Vietnam in general. As our ancestors tried to create meanings of the world around them by telling stories (Cherry, 2017), stories are available in various sources within the reach of almost every teacher and student, even from their personal experiences. Stories are easy to be designed into effective classroom activities which can help students considerably in their learning. Storytelling offers both teachers and learners a lot of benefits in developing communicative competences. This technique can serve as an effective tool to teach speaking and listening skills. Learning with storytelling, students can form special links between words and concepts in their minds. They can also access the words easily when they need to express relevant concepts. These findings can, in fact, strengthen previous authors' belief about the advantages of storytelling in language teaching and learning which have been mentioned and discussed in the literature review.

According to Mutiarani \& Izzah (2015), storytelling can be a very effective teaching tool as long as it is adapted to the pupils' proficiency level, interest, age and need. It is more efficient in the case of younger learners, who have not developed their abstract thinking yet, and who are very creative and imaginative. For better use of storytelling, some recommendations are put forward. Firstly, teachers should choose stories that can arouse students' interest rather than their own's. The selected stories should be suitable to students' level of proficiency as well: They should be neither too difficult nor too easy. Secondly, take advantage of visual aids in storytelling. These things make extra connections between students' life and the content of the stories. Talking with students about their listening 
experience after the story has been told is an important way to develop their "story sense". Also, discussing what they have heard allows students to reflect on the interpretations each of them has of the story and how their own unique life experiences and prior knowledge affect those interpretations. Students need time to explore thoughts and feelings about story characters and events. When a storyteller is ready to examine his or her storytelling style, the teacher might make arrangements to have the storytelling process either audiotaped or videotaped. Students need to be reminded that what is important in the storytelling process includes the shaping of the story, its restructuring, and the exploration of what it was in the story that mattered to them. Although students will strive for improvement, performing a story in a polished way is not the primary purpose. Thirdly, the consolidation stage needs careful preparation from the teachers. Good comprehension and extended questions will help assess students' progress, consolidate the targeted skills, and stimulate the motivation deep inside students' minds. Finally, if an audio recording is used for self-assessment, storytellers might listen for the appropriacy of the use of pauses, intonation, phrasing, certain sound effects, timing, repetition, voice pitch and volume. They can chart these on a checklist they have created for this purpose. When a video is used, students might be expected to assess the effectiveness of posture, visual aids, hand gestures, body movements, or facial expressions. After viewing or listening to the tape and completing the checklist, students could identify one or two areas for improvement.

As previously mentioned, this research is conducted with the participation of 110 children aged from 10 to15 from 10 language centers in Binh Duong province. Within the scope and limited timeframe of the research, the collected data reflect only responses and attitudes from these children in particular, and the recommendations from this research are most suitable for these subjects. What we draw from this research cannot be generalized to all children or all language skills. As the members from the experimental classes are already quite good at English, they are very confident and willing to participate in the storytelling activities. For other cases, the language as well as the topics of stories should be adapted depending on students' fields of interest (such as technology, medicine, sciences, love and so on) for application in teaching adult learners.

\section{CONCLUSION}

This research highlights storytelling as a means to develop children's speaking and listening skills. Conducted with the mixed research methods, the evaluation as well as the recommendations from the study are of great validity and reliability, serving as a reference for language teachers who pay much attention to the technique of storytelling. In teaching English, it is essential that teachers pay great attention to developing speaking and listening skills for learners. Towards these objectives, various activities such as those previously mentioned should be taken into consideration in the process of language teaching and learning. The research proves that storytelling is a very important part of English teaching and learning thanks to its numerous benefits. Students' ability to understand and retell stories in English clearly means that they can communicate efficiently in international working environment later in their professional life. Storytelling not only makes students more active but also makes their language learning more meaningful and interesting.

\section{REFERENCES}

Adrian, D. (1988). Teach English: A Training Course for Teachers. New York: Cambridge University Press.

Amie Sexton (2017). Crafting the Image and Telling the Story - A Cross-cultural Analysis of Winery Identity in France and Australia. The University of Melbourne.

Andrew, W. (1995). Storytelling with Children. Oxford: Oxford University Press.

August, D. \& Shanahan, T. (2006). Developing Literacy in Second Language Learners: Report of the National Literacy Panel on Language Minority Children and Youth. Mahwah, NJ: Lawrence Erlbaum Associates. https://doi.org/10.1080/10862960903340165

Brakke, K., \& Houska, J. A. (2015). Telling stories: The Art and Science of Storytelling as an Instructional Strategy. Retrieved from the Society for the Teaching of Psychology website: http://teachpsych.org/ebooks/ tellingstories.html

Caine, R., \& Caine, G. (1994). Making Connections: Teaching and the Human Brain. Menlo Park, CA: AddisonWesley.

Canlibeka, N. (2019). Exploring the Effects of Digital Storytelling on Young Learners' Motivation, Vocabulary Learning and Retention in Foreign Language Teaching. Master of Arts in ELT, Anada: Cucurova University.

Chaney, A. L., \& Burk T. L. (1998). Teaching Oral Communication in Grades K-8. Boston: Allyn\&Bacon. 
Cherry, R. W. (2017). The Importance of Story and Storytelling in the Classroom. Our Place in the Universe, 46(2), 50-55.

Egan, K. (1992). Imagination in Teaching and Learning - The Middle School Years. University of Chicago Press.

Groce, R. D. (2004). An Experiential Study of Elementary Teachers with the Storytelling Process: Interdisciplinary Benefits Associated with Teacher Training and Classroom Integration. Reading Improvement, 41(2).

Gibson, S. (1990). The Power of Storytelling. Accessed from https://pdf4pro.com/view/1-the-power-of-storytellingin-the-classroom-37676d.html

Hornby, A. S. \& Wehmeier, S. (2000). Oxford Advanced Learner's Dictionary ( $\sigma^{\text {th }}$ ed.). Oxford: Oxford University Press.

Khodabandeh, F. (2018). The Impact of Storytelling Techniques through Virtual Instruction on English Students' Speaking Abilitiy. Teaching English with Technology, 18(1), 24-36.

Lucarevschi, C. R. (2016). The Role of Storytelling in Language Learning: A Literature Review. Working Papers of the Linguistics Circle, 26(1), 24-44.

Mandler, J.M. \& Johnson, N.S. (1977). Remembrance of Things Parsed: Story Structure and Recall. Cognitive Psychology, 9(1), 111-51. https://doi.org/10.1016/0010-0285(77)90006-8

Mutiarani and Izzah (2015). The Power of Storytelling in Teaching English to Young Learners. University of Muhammadiyah, Japan.

Octaviana, D. W. (2017). Teaching English to Young Learners. Journal of English Teaching and Research, 2(2), 124-133. https://doi.org/10.29407/jetar.v2i2.808

Prince's (1973). A Grammar of Stories. The Hague: Mouton.

Schumacher, S. \& McMillan, J. H. (1993). Research in Education: A Conceptual Introduction ( $3^{\text {rd }}$ edition). Harper Collins College Publishers.

Sever, T. (2014). An Investigation into the Impact of Digital Storytelling on the Motivation Level of Students. Unpublished MA Thesis, 1-142. Çanakkale, Turkey: Çanakkale Onsekiz Mart University, Institute of Education Sciences.

Shank, M. J. (2006). Teacher Storytelling: A Means for Creating and Learning within a Collaborative Space. Teaching and Teacher Education, 22(6), 711-721.

U.S. Department of Education (1986). What Works about Teaching and Learning. Accessed from https://mazgeenlegendary.wordpress.com/storytelling-in-education 